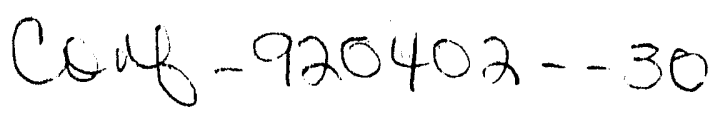

\title{
Processing and Properties of Silver-Clad Tl-Ba-Ca-Cu-O Wires and Tapes*
}

K. C. Goretta, C.-T. Wu, M. T. Lanagan, M. A. Boling, Donglu Shi, D. J. Miller, Nan Chen, W. G. Hanewald, S. Sengupta, Z. Wang, and R. B. Poeppel Argonne National Laboratory, Argonne, IL 60439-4838 USA

\author{
F. Foong and S. H. Liou \\ University of Nebraska, Lincoln, NE 68588-0111 \\ ANL/CP-74829
}

DE92 015266

March 1992

The submited manusctipl has been authored by
a contractor of the U.S. Government under
contract No. W-31-109-ENG-38. Accordingly, the
U.S. Government retains a nonexclustve, royaky-
tree Ilcense to publtsh or reproduce the published
lorm of thi contribution, or allow others to do so.
for U.S. Govemment purposes.

\section{DISCLAIMER}

This report was prepared as an account of work sponsored by an agency of the United States Government. Neither the United States Government nor any agency thereof, nor any of their employees, makes any warranty, express or implied, or assumes any legal liability or responsibility for the accuracy, completeness, or usefulness of any information, apparatus, product, or process disclosed, or represents that its use would not infringe privately owned rights. Reference herein to any specific commercial product, process, or service by trade name, trademark, manufacturer, or otherwise does not necessarily constitute or imply its endorsement, recommendation, or favoring by the United States Government or any agency thereof. The views and opinions of authors expressed herein do not necessarily state or reflect those of the United States Government or any agency thereof.

Paper submitted for publication in Proceedings of 1992 Spring Meeting of the Materials Research Society, San Francisco, CA, April 27-May 1, 1992.

*The work at Argonne was supported by the U.S. Department of Energy (DOE), Offices of Conservation and Renewable Energy, as part of a DOE program to develop electric power technology, and Basic Energy Sciences-Materials Sciences, under Contract W-31-109-Eng-38. The work of WGH was supported by the Argonne Division of Educational Programs with funding from DOE. The work at the University of Nebraska was supported by NASA Lewis Grant NAG 3-866, the Nebraska University Foundation, and the Nebraska Energy Office.

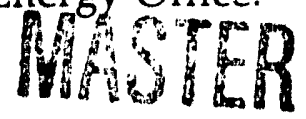


K. C. GORETTA,* C.-T. WU,* M. T. LANAGAN,* M. A. BOLING, ${ }^{*}$ DONGLU SHI,* D. J. MILLER,* NAN CHEN,* W. G. HANEWALD,* S. SENGUPTA,* Z. WANG, ${ }^{*}$ R. B. POEPPEL, ${ }^{*}$ F. FOONG, ${ }^{* *}$ and S. H. LIOU**

*Argonne National Laboratory, Argonne, IL 60439-4838

**University of Nebraska, Lincoln, NE 68588-0111

\section{ABSTRACT}

$\mathrm{TlBa}_{2} \mathrm{Ca}_{2} \mathrm{Cu}_{3} \mathrm{O}_{\mathrm{x}}$ and $\mathrm{Tl}_{2} \mathrm{Ba}_{2} \mathrm{Ca}_{2} \mathrm{Cu}_{3} \mathrm{O}_{\mathbf{x}}$ powders were synthesized, loaded into $\mathrm{Ag}$ tubes, and worked into wires and tapes by drawing and rolling. All processing outside of furnaces was in a dry- $\mathrm{N}_{2}$ glovebox. All heat treatments were performed in $\mathrm{O}_{2}$. The $\mathrm{Ag}$-clad wires fabricated from these powders exhibited onset of superconductivity at $\approx 118 \mathrm{~K}$ and critical current densities at $77 \mathrm{~K}$ of $2 \times 10^{3}$ to $4 \times 10^{3} \mathrm{~A} / \mathrm{cm}^{2}$.

\section{INTRODUCTION}

Tl-based superconductors have the highest confirmed $T_{c}$ values [1] and $\ldots r \ldots i$ to have better resistance to flux creep than do the Bi-based superconductors [2-5]. In fact, the $\mathrm{TlBa}_{2} \mathrm{Ca}_{2} \mathrm{Cu}_{3} \mathrm{O}_{\mathrm{x}}$ (1223) compound has inherent flux-pirning characteristics superior to those of all high-temperature superconductors other than $\mathrm{YBa}_{2} \mathrm{Cu}_{3} \mathrm{O}_{\mathbf{x}}[2]$. It has proved to be very difficult to fabricate wires from $\mathrm{YBa}_{2} \mathrm{Cu}_{3} \mathrm{O}_{x}$ that do not suffer from weak-link problems $[6,7]$. It is hoped that the 1223 and $\mathrm{Tl}_{2} \mathrm{Ba}_{2} \mathrm{Ca}_{2} \mathrm{Cu}_{3} \mathrm{O}_{x}$ (2223) compounds will be easier to work into wires and tapes than is $\mathrm{YBa}_{2} \mathrm{Cu}_{3} \mathrm{O}_{x}$. Encouraging preliminary results on the current-transport properties of $\mathrm{Tl}-\mathrm{Ba}-\mathrm{Ca}-\mathrm{Cu}-\mathrm{O}$ have been reported for both clad wires $[4,8]$ and thick films [9].

The goals of this work were to fabricate 1223 and $2223 \mathrm{Ag}$-clad wires and to determine whether the superconducting properties were dominated by weak links, and if not, how the properties were dependent on composition and processing.

\section{EXPERIMENTAL METHODS}

The 12.23 powder was synthesized from high-purity $\mathrm{BaCO}_{3}, \mathrm{CaCO}_{3}, \mathrm{CuO}$, and $\mathrm{Tl}_{2} \mathrm{O}_{3}$. A Ba $\mathrm{Ca}_{2} \mathrm{Cu}_{3} \mathrm{O}_{\mathrm{x}}$ powder was made first and then mechanically mixed with $\mathrm{Tl}_{2} \mathrm{O}_{3}$ [10]. The powders were screened through an 80-mesh sieve three times during the mixing. To minimize contact with $\mathrm{CO}_{2}$ or $\mathrm{H}_{2} \mathrm{O}$, the mixing was performed within $15 \mathrm{~min}$ in a dry- $\mathrm{N}_{2}$ glovebox. Approximately $15 \mathrm{~g}$ of the mixed powder was placed in a small $\mathrm{Pt}$ crucible that had a tight $\mathrm{Ag}$ lid and heated to $900^{\circ} \mathrm{C}$, held for $0.1 \mathrm{~h}$, cooled to $885^{\circ} \mathrm{C}$ and held for $12 \mathrm{~h}$, and then cooled at about $3^{\circ} \mathrm{C} / \mathrm{min}$ to room temperature. The short time at $900^{\circ} \mathrm{C}$ was designed to introduce a small amount of liquid phase so that the synthesis reaction kinetics could be accelerated [11]. The powder was crushed and given a second identical heat treatment. The final powders were removed from the furnace to the glovebox while still hot. The $T_{C}$ onset of the powder was $\approx 120 \mathrm{~K}$.

For the 2223 powder, the $\mathrm{Ba}_{2} \mathrm{Ca}_{2} \mathrm{Cu}_{3} \mathrm{O}_{x}$ precursor powder was made from $\mathrm{BaO}, \mathrm{CaO}$, and $\mathrm{CuO}$. The mixture was ground thoroughly and pressed into 
pellets that were sintered at $930^{\circ} \mathrm{C}$ in flowing $\mathrm{O}_{2}$ for $\pm 8 \mathrm{~h}$. After the reaction was completed, $\mathrm{Tl}_{2} \mathrm{O}_{3}$ powder was added to form the nominal composition Tl1.5 $\mathrm{Ba}_{2} \mathrm{Ca}_{2} \mathrm{Cu}_{3} \mathrm{O}_{\mathrm{x}}$. The mixture was pressed into pellets and heated in a sealed crucible filled with $\mathrm{O}_{2}$ at $300^{\circ} \mathrm{C}$ for $10 \mathrm{~h}$. To improve homogeneity, the heat treatment was repeated after an intermediate grinding. The final powder had a $\mathrm{T}_{\mathrm{C}}$ onset of $\approx 120 \mathrm{~K}[12]$.

Ag-clad wires were fabricated by a powder-in-tube process [13]. The powders were loaded into closed-end tubes of $6.35 \mathrm{~mm}$ outer diameter and $4.35 \mathrm{~mm}$ inner diameter. The powder was vibrated and rammed to assist compaction. The tubes were evacuated, sealed, and drawn at $\approx 15 \%$ reduction per pass to a diameter of $1.8 \mathrm{~mm}$. After every third drawing pass, the tubes were annealed at $260^{\circ} \mathrm{C}$ for $20 \mathrm{~min}$ to preserve the ductility of the Ag. In an attempt to produce favorable textures, some of the tubes were were further reduced by flat rolling at $10 \%$ reduction per pass. The thicknesses of the resultant tapes were $\approx 450 \mu \mathrm{m}$.

The powders and wires and tapes were characterized by X-ray diffraction, scanning and transmission electron microscopy (SEM and TEM), and differential thermal analysis (DTA). The DTA was performed in flowing $\mathrm{O}_{2}$, with a heating rate of $5^{\circ} \mathrm{C} / \mathrm{min}$. DTA was also performed on small amounts of the unreacted powders to monitor the synthesis reactions.

Several sintering schedules were used for the wires and tapes. Sintering was performed in the solid state or with partial melting. The 1223 and 2223 powders had onsets of melting in $\mathrm{O}_{2}$ of 905 and $890^{\circ} \mathrm{C}$, respectively. As shown in Fig. 1, however, the presence of the Ag sheath lowered the melting temperatures for each by about $45^{\circ} \mathrm{C}$. Partial-melt heat treatments incorporated heating for 6-12 min at temperatures as high as $900^{\circ} \mathrm{C}$ for the 1223 and $885^{\circ} \mathrm{C}$ for the 2223 . Higher temperatures or longer times at temperature resulted in perforation of the $\mathrm{Ag}$.

A commercial SQUID magnetometer was used to measure $T_{c}$. Transport critical current density $\left(\mathrm{J}_{\mathrm{C}}\right)$ values were obtained at 4.2 and $77 \mathrm{~K}$. A standard fourprobe method with a voltage criterion of $1 \mu \mathrm{V} / \mathrm{cm}$ was used. In addition, magnetic-hysteresis measurements were performed on a few samples with a commercial vibrating-specimen magnetometer containing a superconducting magnet in a gas-flow-type cryostat.

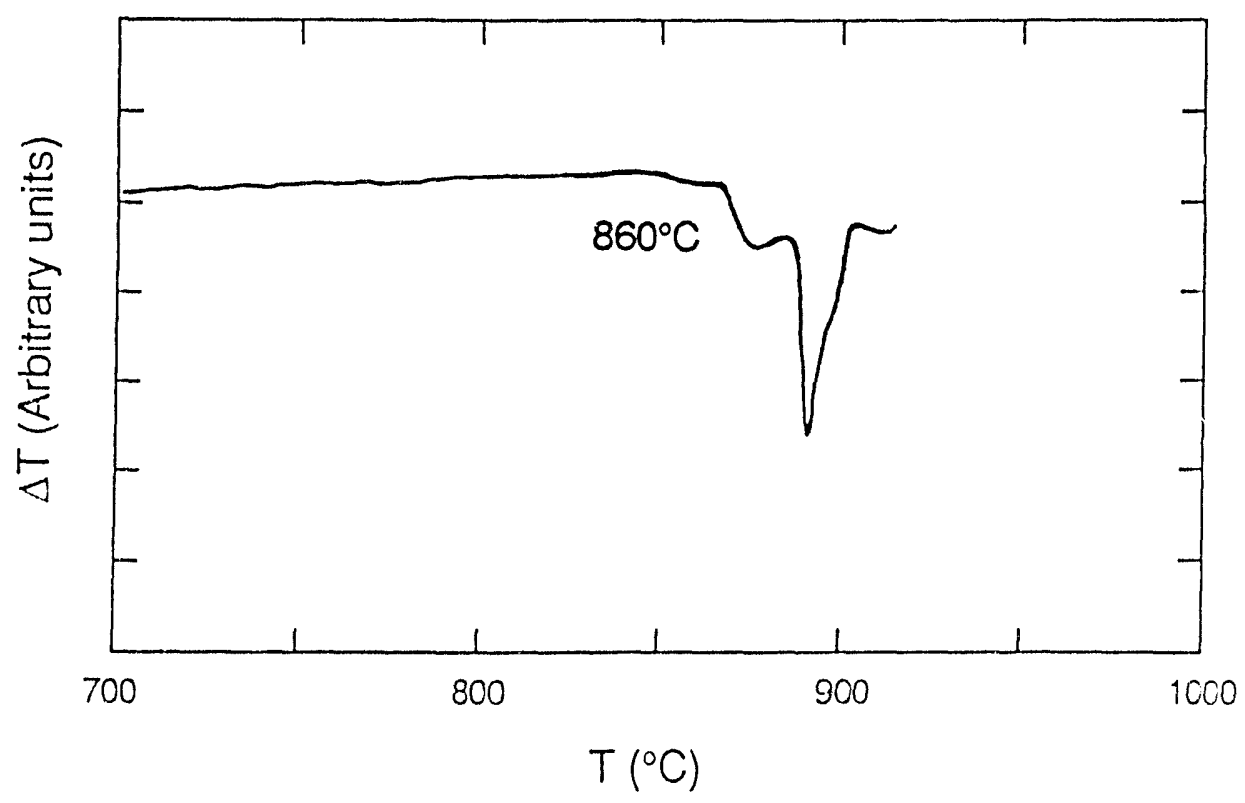

Fig. 1. DTA trace in $\mathrm{O}_{2}$ of $1223+\mathrm{Ag}$ powder. 


\section{RESULTS AND DISCUSSION}

The initial porvders were greater than $90 \%$ phase pure. It has been reported that extensive substitution occurs on the $\mathrm{Tl}$ site in $2223[14,15]$, and thus the $\mathrm{Tl}-$ deficient composition used was able to produce 2223 of good phase purity. Although some $\mathrm{CaO}$ and $\mathrm{BaCuO}_{2}$ were observed in the powders, the phases were present in small isolated pockets. The total carbon contents of the $\mathrm{Ba}_{2} \mathrm{Ca}_{2} \mathrm{Cu}_{3} \mathrm{O}_{\mathrm{x}}$ powders were less than $0.02 \%$. Carbon can have deleterious effects on the properties of bulk high-temperature superconductors, but $0.02 \%$ is the concentration quoted for $(\mathrm{Bi}, \mathrm{Pb})_{2} \mathrm{Sr}_{2} \mathrm{Ca}_{2} \mathrm{Cu}_{3} \mathrm{O}_{\mathrm{x}} / \mathrm{Ag}$ tapes with good electrical properties [16]. The process of adding the $\mathrm{Tl}$ to the $\mathrm{Ba}_{2} \mathrm{Ca}_{2} \mathrm{Cu}_{3} \mathrm{O}_{x}$ was not expected to introduce appreciable carbon.

The superconducting properties of Ag-clad wires were dependent on heat treatment. Sintering schedules for the wires included either long heat treatments at $845^{\circ} \mathrm{C}$ for the 1223 and $830^{\circ} \mathrm{C}$ for the 2223 , which occurred entirely in the solid state, or shorter-term heat treatments to temperatures of $870-900^{\circ} \mathrm{C}$ followed by an anneal in the solid state. For the partially melted wires and tapes, annealing at $830-845^{\circ} \mathrm{C}$ was necessary to raise the $T_{c}$ onset to $118 \mathrm{~K}$, although the transition was somewhat broad for most of the wires. In the absence of the 830$845^{\circ} \mathrm{C}$ anneal, the $\mathrm{T}_{\mathrm{C}}$ values were $100-110 \mathrm{~K}$ and the transitions were very broad. No further attempts were made to optimize $T_{c}$ by annealing at other temperatures or in other atmospheres [14]. For all of the better specimens, the $\mathrm{J}_{\mathrm{C}}$ values ranged from $2 \times 10^{3}-4 \times 10^{3} \mathrm{~A} / \mathrm{cm}^{2}$ at $77 \mathrm{~K}$. These values increased to about $4 \times 10^{3}-10^{4}$ at $4.2 \mathrm{~K}$. The partially inelted specimens generally exhibited slightly higher $\mathrm{J}_{\mathrm{C}}$ values, but as shown in Fig. 2 , the $\mathrm{J}_{\mathrm{C}}$ values decreased rapidly in an applied magnetic field. Thus, the properties of these wires and tapes were determined by weak links, not flux pinning.

The $\mathrm{J}_{\mathrm{c}}$ values of the $\mathrm{Tl}-\mathrm{Ba}-\mathrm{Ca}-\mathrm{Cu}-\mathrm{O} / \mathrm{Ag}$ wires and tapes were below those quoted for melt-textured materials or $\mathrm{Ag}$-clad $(\mathrm{Bi}, \mathrm{Pb})_{2} \mathrm{Sr}_{2} \mathrm{Ca}_{2} \mathrm{Cu}_{3} \mathrm{O}_{\mathrm{x}}$ tapes $[7,16-$ 18]. Relatively little fabrication work has been done to date, and properties are expected to improve.

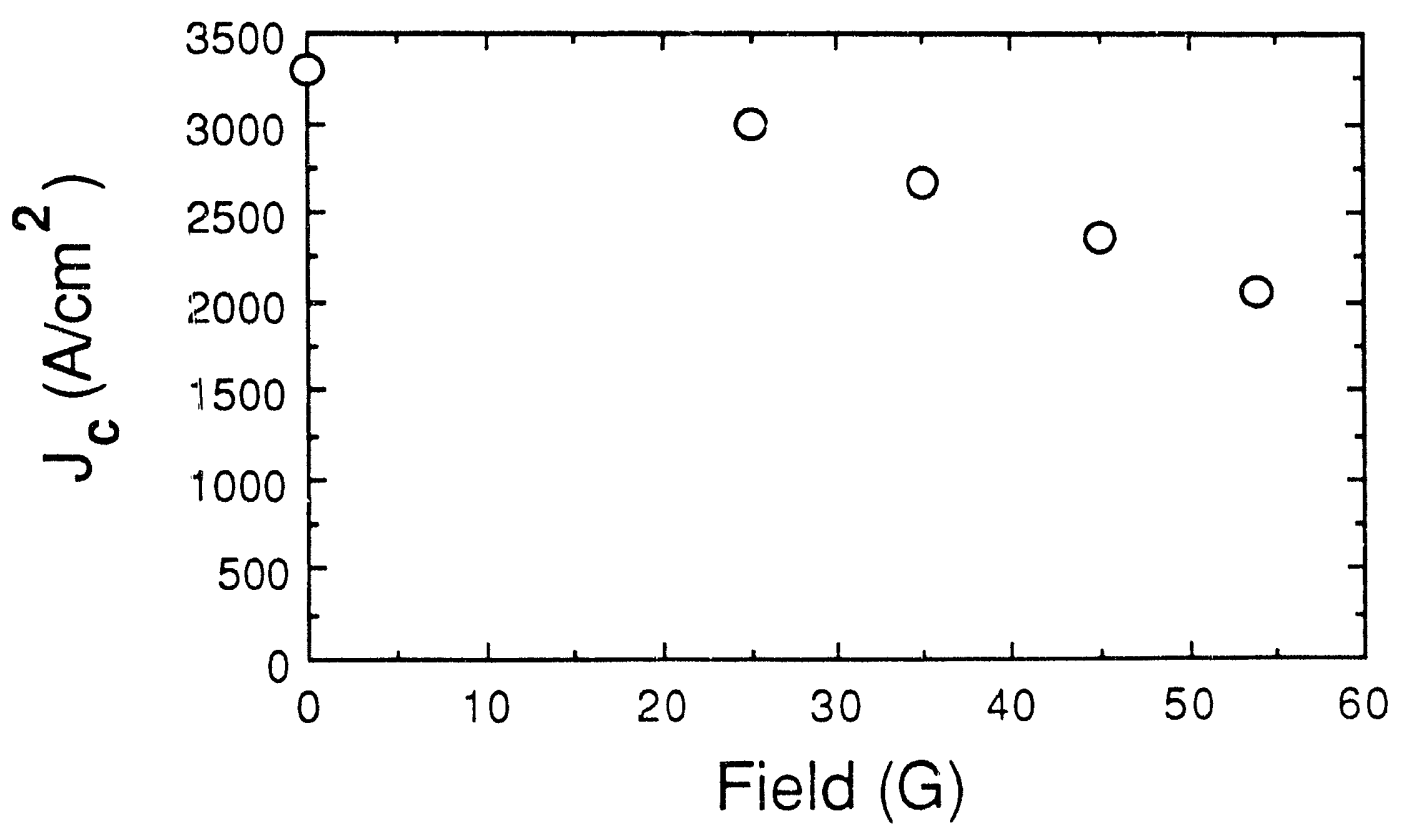

Fig. 2. Jc versus applied field at $77 \mathrm{~K}$ for a $1223 / \mathrm{Ag}$ tape. 
Representative magnetization data for $1223 / \mathrm{Ag}$ tapes are shown in Fig. 3. $\left(\mathrm{J}_{\mathrm{c}}\right.$ values were not calculated because of uncertainties in how to apply the Bean model.) Two important results emerged. First, the $J_{c}$ would appear to have been higher with the applied magnetic prependicular to the plane of the tape than parallel to it. Thus, the flat rolling procedures must have been ineffective in causing the grains to align favorably. Second, the fields at which the hysteresis loops collapsed were less than those reported for the irreversibility line in 1223 by Kim et al. [2]. It is unknown why this is so.
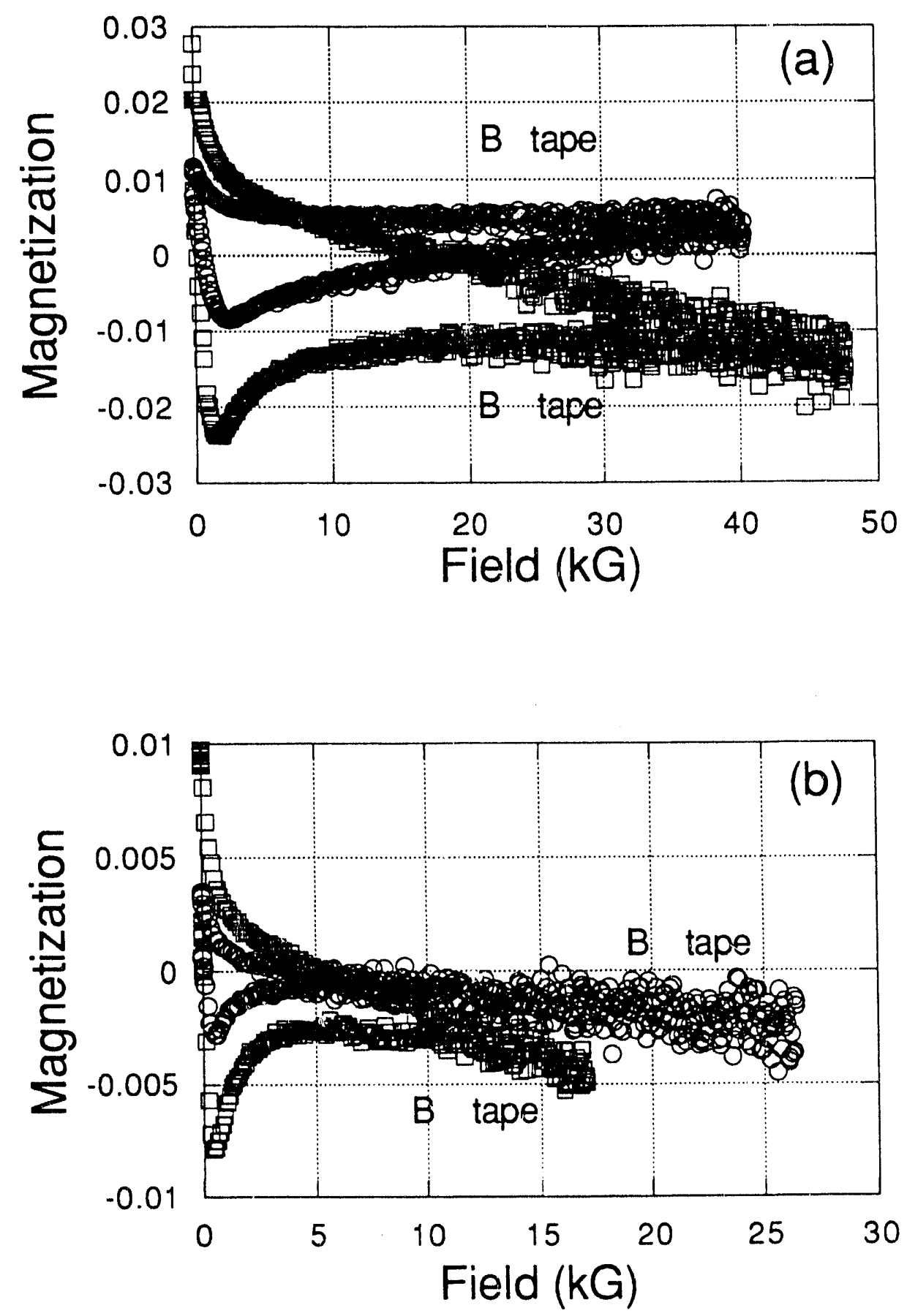

Fig. 3. Hysteresis data at (a) $40 \mathrm{~K}$ and (b) $77 \mathrm{~K}$ for $1223 / \mathrm{Ag}$ tapes that were sintered in $\mathrm{O}_{2}$ at $890^{\circ} \mathrm{C}$ and then annealed at $845^{\circ} \mathrm{C}$. 
SEM and TEM examinations of the wires revealed very complex microstructures. $\mathrm{CaO}$ and $\mathrm{BaCuO}_{2}$ phases were observed in all of the wires and tapes, but were much more prevalent in those that had been partially melted. These phases were all present as discrete grains; they did not coat grain boundaries (Fig. 4). No clear alignment of the grains was observed in either the wires or the tapes, which is in accordance with the magnetization measurements. Intergrowths were present in all of the superconductor grains examined. Given these poor microstructures, it was somewhat surprising that the $\mathrm{J}_{\mathrm{c}}$ values were greater than $10^{3} \mathrm{~A} / \mathrm{cm}^{2}$ at $77 \mathrm{~K}$.

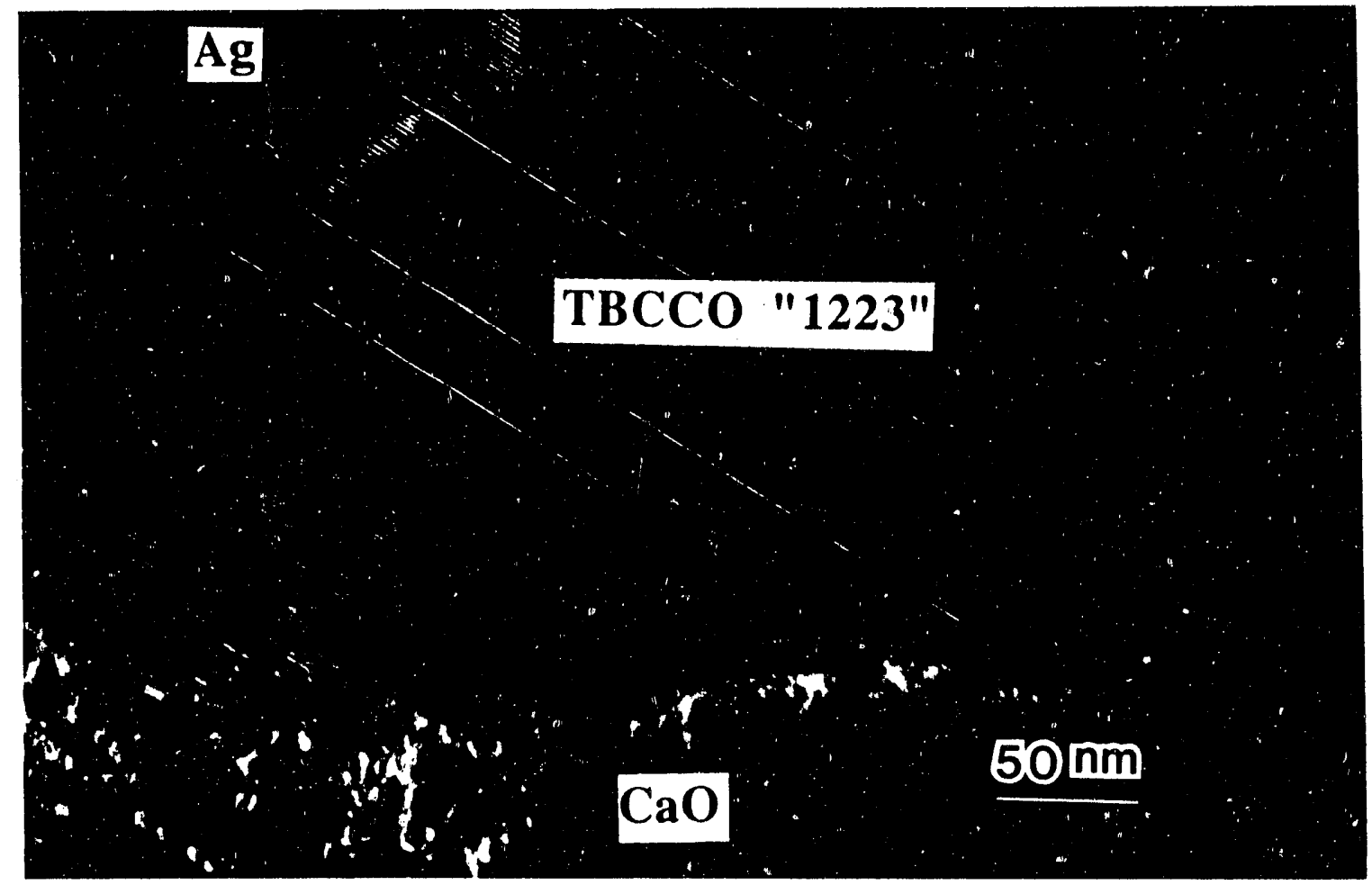

Fig. 4. 'TEM photomicrograph of 1223 / Ag tape containing 1223 and $\mathrm{CaO}$ grains.

\section{SUMMARY}

$\mathrm{Ag}$-clad wires and tapes :nade from 1223 and $2223 \mathrm{Tl}-\mathrm{Ba}-\mathrm{Ca}-\mathrm{Cu}-\mathrm{O}$ powders had $T_{C}$ values of $\approx 118 \mathrm{~K}$ and $J_{c}$ values at $77 \mathrm{~K}$ of $2 \times 10^{3}-4 \times 10^{3} \mathrm{~A} / \mathrm{cm}^{2}$. All specimens exhibited weak-link behavior. The initial powders had good phase purities, but the final microstructures contained large concentrations of second phases. No favorable grain alignment was observed.

\section{ACKNOWLEDGMENTS}

The work at Argonne was supported by the U.S. Department of Energy (DOE), Offices of Conservation and Renewable Energy, as part of a DOE program to develop electric power technology, and Basic Energy Sciences-Materials Sciences, under Contract W-31-109-Eng-38. The work of WGH was supported by the Argonne Division of Educational Programs with funding from DOE. The work at the University of Nebraska was supported by NASA Lewis Grant NAG 3-866, the Nebraska University Foundation, and the Nebraska Energy Office. 


\section{REFERENCES}

1. S. S. P. Parkin, V. Y. Lee, E. M. Engler, A. I. Nazzal, T. C. Huang, G. Gorman, R. Savoy, and R. Beyers, Phys. Rev. Lett. 60, 2539 (1988).

2. D. H. Kim, K. E. Gray, R. T. Kampwirth, J. C. Smith, D. S. Richeson, T. J. Marks, J. H. Kang, J. Talvacchio, and M. Eddy, Physica C 177 431 (1991).

3. T. Sasoaka, A. Nomoto, M. Seido, T. Doi, and T. Kamo, Jpn. J. Appl. Phys. $\underline{30}$ L1868 (1991).

4. S.-P. Matsuda, T. Doi, A. Soeta, T. Yuasa, N. Inoue, K. Aihara, and T. Kamo, Appl. Phys. Lett. 59,3186 (1991).

5. M. Mittag, M. Roseberg, B.Himmerich, and H. Sabrowsky, Supercond. Sci. Technol. 4 , 244 (1991).

6. K. Osamura, T. Takayama, and S. Ochiai, Appl. Phys. Lett. 55 396 (1989).

7. S. Jin and J. E. Graebner, Mater. Sci. Eng. B7, 243 (1991).

8. M. Okada, R. Nishiwaki, T. Kamo, T. Matsumoto, K. Aihara, S. Matsuda, and M. Seido, Jpn. J. Appl. Phys. 27, L2345 (1988).

9: J. A. DeLuca, General Electric, Schenectady, NY, private communication, 1992.

10. K. C. Goretta, N. Chen, M. T. Langan, S. E. Dorris, J. Hu, C.-T. Wu, and R. B. Poeppel, unpublished results.

11. I. Bloom, J. R. Frommelt, M. C. Hash, M. T. Lanagan, C.-T. Wu, and K. C. Goretta, Mater. Res. Bull. 26, 1269 (1991).

12. S. H. Liou, V. K. Chan, F. Foong, W. Y. Lee, Y. S. Gou, and T. M. Uen, IEEE Trans. Magn. 27, 1227 (1991).

13. C.-T. Wu, K. C. Goretta, D. Shi, M. T. Lanagan, and R. B. Poeppel, in High Temperature Superconducting Compounds III, ed. S. H. Whang, A. DasGupta, and E. W. Collings (The Metall. Soc., Warrendale, PA, 1991) p. 375.

14. A. Schilling, H. R. Ott, and F. Hulliger, Physica C 157, 144 (1989).

15. R. M. Iyer, G. M. Phatak, K. Gangadharan, M. D. Sastry, R. M. Kadam, P. V. P. S. S. Sastry, and J. V. Yakhmi, Physica C 160155 (1989).

16. Y. Yamada, B. Obst, and R. Flükiger, Supercond. Sci. Technol. 4, 165 (1991).

17. K. Sato, T. Hikata, and Y. Iwasa, Appl. Phys. Lett. 57, 1928 (1990).

18. H. Sekine, J. Schwartz, T. Kuroda, K. Inoue, H. Maeda, K. Numata, and H. Yamamoto, J. Appl. Phys. 70, 1596 (1991). 

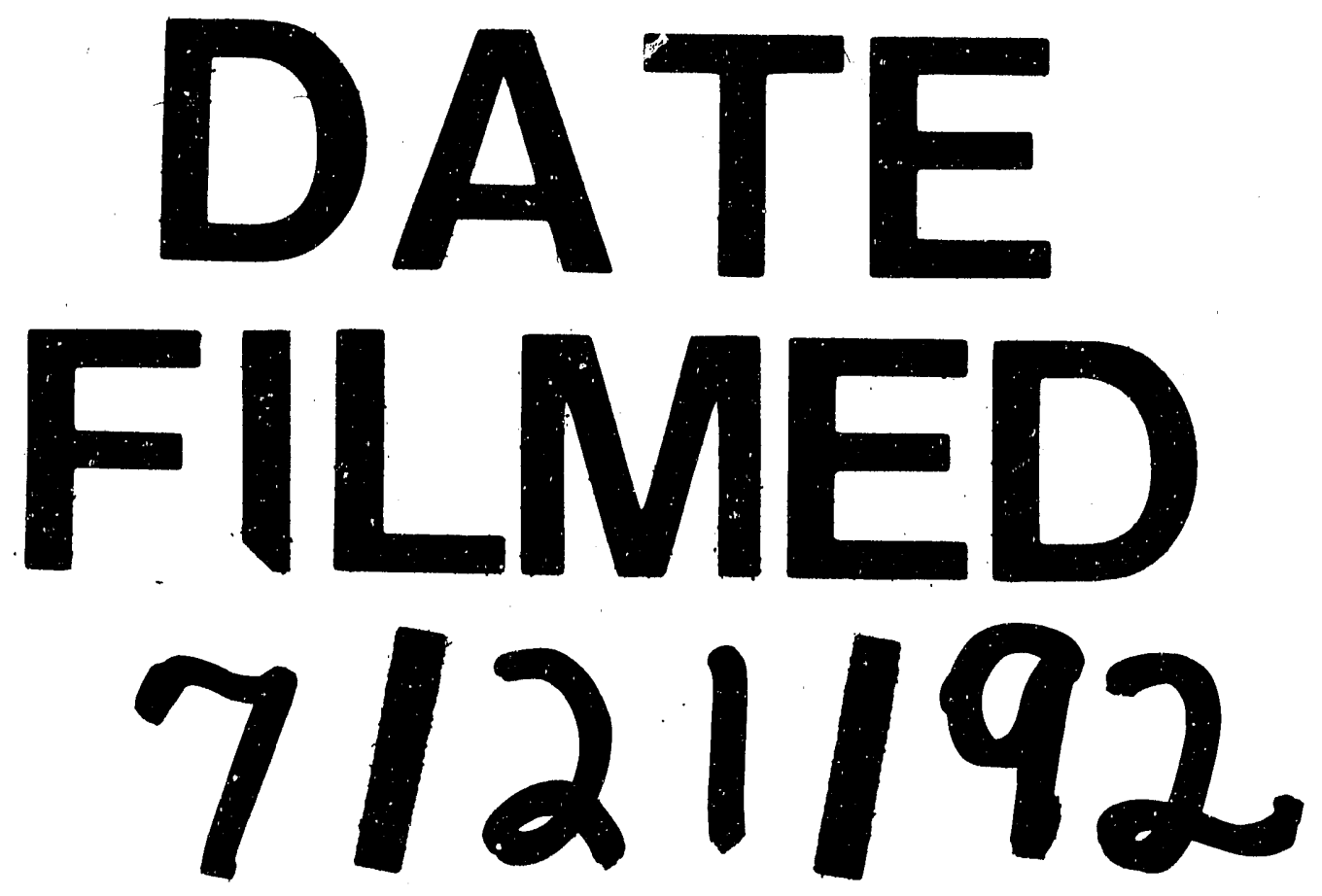


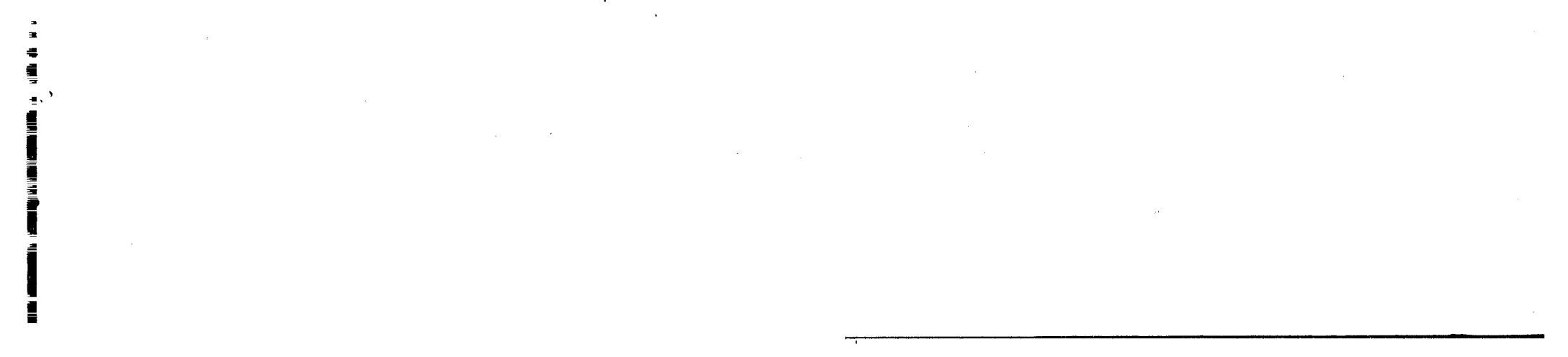

